PURBAwIdyA: Jurnal Penelitian dan Pengembangan Arkeologi p-ISSN: 2252-3758, e-ISSN: 2528-3618 Akreditasi LIPI No. 695/Akred/ P2MI-LIPI/07/2015

Vol. 7(1), Juni 2018, pp $21-34$ DOI: https://doi.org/10.24164/pw.v7i1.256

\title{
IDENTIFIKASI PENGGUNAAN LAHAN BERDASARKAN SUMBER PRASASTI ABAD KE-11 MASEHI DI JAWA TIMUR
}

\section{Identification of Land Use Based on InscriptionsFrom $11^{\text {th }}$ Century A.D in East Java}

\author{
Siswanto \\ Balai Arkeologi Jawa Barat \\ Jalan Raya Cinunuk Km 17, Cileunyi, Bandung \\ E-mail: sswanto.id@gmail.com \\ Naskah diterima 2 Maret 2018 - Revisi terakhir 23 Juni 2018 \\ Disetujui terbit 15 Juli 2018 - Tersedia secara online 1 Agustus 2018
}

\begin{abstract}
This article discusses the use of ancient Javanese ancient land based on the source of the 11th century AD inscription in East Java. The problem in this paper focus on what kind of land use during the ancient Javanese period based on the inscription of the 11th century AD. Inscriptions as the main data were studied using the epigraphic method. Analysis based on the source of the inscription that provides complete information about the life of ancient Javanese in relation to land use. The results of the inscription analysis indicate that there are six forms of land use that have been done, namely; settlements, rice fields, gardens, dams (and also canals), religious buildings, and forests. Forms of land use in the form of rice fields, gardens, dams and canals associated strongly with agricultural activities. Reasons related to land use indicate the dominance of strong political reasons. This is because in the 11th century AD especially during the Airlanga and its successors were the events of war and the enforcement of power so that many inscriptions contain political reasons. Although some inscriptions contain religious reasons but the numbers are not too many. However, it remains the political reason that dominates in the inscription description.
\end{abstract}

Keywords: Land use, Inscriptions, Airlanga

\begin{abstract}
Abstrak
Artikel ini membahas tentang penggunaan lahan masa Jawa kuno berdasarkan sumber prasasti abad ke-11 Masehi di Jawa Timur. Permasalahan pada tulisan ini adalah apa saja bentuk penggunaan lahan masa Jawa kuno berdasarakan prasasti abad ke-11 Masehi. Prasasti-prasasti sebagai data utama dikaji menggunakan metode epigrafi. Analisis berdasarkan sumber prasasti yang memberikan informasi lengkap mengenai kehidupan masa Jawa kuno kaitannya dengan pemanfaatan lahan. Hasil analisis prasasti menunjukkan bahwa terdapat enam bentuk penggunaan lahan yang pernah dilakukan, yaitu permukiman, sawah, kebun, serta bendungan (dan juga kanal), bangunan keagamaan, dan hutan. Bentuk penggunaan lahan berupa sawah, kebun, bendungan
\end{abstract}


dan kanal berkaitan kuat dengan kegiatan pertanian. Alasan terkait penggunaan lahan menunjukkan dominasi alasan politik yang kuat. Hal itu disebabkan pada abad ke-11 Masehi, terutama pada masa Airlanga dan penerusnya, terjadi peristiwa peperangan dan penegakan kekuasaan sehingga banyak prasasti memuat alasan politik. Beberapa prasasti memuat alasan religi, tetapi jumlahnya tidak terlalu banyak. Namun, tetap alasan politik yang mendominasi dalam uraian prasasti.

Kata kunci: penggunaan lahan, prasasti, Airlanga

\section{PENDAHULUAN}

Masa Indonesia kuno dipengaruhi kebudayaan Hindu-Buddha dengan peninggalannya berupa budaya materi, salah satunya adalah prasasti. Secara umum data prasasti adalah sumber sejarah paling penting (Kusumohartono, 1994) karena memuat banyak informasi mengenai kehidupan pada masa pengaruh HinduBuddha di Indonesia. Informasi yang dimaksud di antaranya adalah kegiatan ekonomi, sosial-politik, hukum, religi, bahkan informasi mengenai penggunaan lahan juga dapat dicari lewat data prasasti.

Salah seorang raja yang pernah memerintah di Jawa Timur pada masa Jawa Kuno adalah Airlangga. Awalnya Airlanga merupakan menantu dari Dharmmawañśa Tguh. Pada berlangsungnya pesta pernikahan Airlanga dengan anak dari Dharmmawañśa Tguh, kerajaan diserang oleh Haji Wurawari. Akibat serangan itu Airlanga terpaksa melarikan diri ke hutan bersama Narottama (De Casparis, 1958).

Berdasarkan sumber prasasti dari abad ke-11 Masehi, Airlanga telah membuat bendungan untuk memperbaiki kondisi lahan pertanian di seluruh hilir.

Prasasti-prasasti abad ke-11 Masehi yang berhubungan dengan Airlanga menempati bentang lahan berbeda-beda. Lokasi-lokasi tersebut berupa daerah aliran sungai (DAS) Solo dan Brantas, Gunung
Penanggungan, dan Pegunungan Kendeng. Jumlah prasasti yang cukup banyak dan lokasi penemuan yang berbeda menarik dikaji lebih lanjut sehingga memunculkan pertanyaan apa saja bentuk penggunaan lahan masa Jawa kuna berdasarkan prasasti abad ke-11 Masehi?

Informasi mengenai penggunaan lahan banyak dikaji pada masa sekarang. Hal itu dipengaruhi oleh berkembangnya ilmu pengetahuan dan banyaknya kepentingan yang terkait dengan lahan. Masalah penggunaan lahan pada masa Jawa kuno menarik dikaji karena dapat mengetahui kecenderungan usaha pemanfaatan lahan dari waktu ke waktu. Selain itu, kajian identifikasi bentuk penggunaan lahan masa Jawa kuno dapat digunakan untuk mengetahui alasan suatu penguasa dalam memanfaatkan lahan dalam wilayah kekuasaannya.

Prasasti-prasasti masa Airlanga dan raja-raja setelahnya, dipilih enam prasasti yang dianggap mewakili kluster temuan prasasti sebagai data penelitian. Kluster temuan prasasti dibagi berdasarkan kedekatan antarprasasti satu dan lainnya. Prasasti-prasasti yang cukup dekat dengan lainnya dianggap sebagai sebuah kluster temuan. Prasasati tesebut adalah sebagai berikut.

Tabel 1. Daftar Prasasti yang Digunakan Sebagai Data Penelitian 


\begin{tabular}{|c|c|c|}
\hline Prasasti & Tahun & Sumber \\
\hline Pātakan & 1021 & $\begin{array}{l}\text { Brandes, 1913: } \\
\text { 125-128; Christie, } \\
\text { 1999: } 385\end{array}$ \\
\hline $\begin{array}{l}\text { Tĕrĕp I } \\
\text { \& II }\end{array}$ & 1032 & $\begin{array}{l}\text { Christie, 1999: } \\
\text { 395-396; Damais, } \\
\text { 1952: A139; Da- } \\
\text { mais, 1955: 65-66; } \\
\text { Wurjantoro 2012: } \\
\text { 324-330 }\end{array}$ \\
\hline $\begin{array}{l}\text { Turun } \\
\text { Hyan A }\end{array}$ & 1036 & $\begin{array}{l}\text { Christie, 1999: } \\
\text { 397; Brandes, } \\
\text { 1913: 143-146; }\end{array}$ \\
\hline $\begin{array}{l}\text { Kamalag- } \\
\text { yan }\end{array}$ & 1037 & $\begin{array}{l}\text { Christie, 1999: } \\
\text { 398; Brandes, } \\
\text { 1913: 134; Da- } \\
\text { mais, 1952: A140; } \\
\text { Damais, 1955: } \\
\text { 161; Susanti } \\
\text { 1996/97: 31-37 } \\
\end{array}$ \\
\hline Sumĕnka & 1059 & $\begin{array}{l}\text { Christie, 1999: } \\
\text { 432; Damais, } \\
\text { 1952: A144; } \\
\text { Damais, 1955: } \\
\text { 141-143 }\end{array}$ \\
\hline $\begin{array}{l}\text { Kusamb- } \\
\text { yan }\end{array}$ & $?$ & $\begin{array}{l}\text { Widayanto 2004; } \\
\text { Nastiti 2014: 69- } \\
79\end{array}$ \\
\hline
\end{tabular}

Prasasti tersebut dikaji menggunakan kajian epigrafi (Dwiyanto, 1993). Kajian tersebut bertujuan untuk menghasilkan intepretasi, yaitu identifikasi bentuk penggunaan lahan berdasarkan sumber prasasti abad ke-11 Masehi di Jawa Timur.

Selain menggunakan prasasti sebagai data utama, digunakan berita dari naskahnaskah sastra. Berita dari naskah sastra digunakan untuk memberikan gambaran lebih jelas mengenai penggunaan lahan masa Jawa kuna karena uraian prasasti tidak selalu memberikan gambaran yang jelas. Hal tersebut disebabkan tidak semua prasasti berisi gambaran kondisi lingkungan.

\section{HASIL DAN PEMBAHASAN}

Identifikasi penggunaan lahan pada beberapa prasasti dari abad ke-11 Masehi menunjukkan adanya permukiman, pertanian, bangunan keagamaan, dan hutan. Penggunaan lahan untuk pertanian terdapat tiga bentuk, yaitu sawah, kebun, dan bendungan (serta kanal). Penggolongan bendungan dan kanal sebagai bagian dari kegiatan pertanian disebabkan perannya yang lebih banyak sebagai sarana pendukung kegiatan petanian.

\section{- Permukiman}

Permukiman dalam penelitian ini ditemukan berdasarkan penyebutan nama thāni (desa). Informasi nama thāni atau dalam pengertian sekarang disebut sebagai toponim atau nama geografis. Prasasti-prasasti yang digunakan sebagai data penelitian seluruhnya menyebutkan toponim desa. Mengacu pada toponim yang disebutkan dalam prasasti, digunakan sebagai dasar intepretasi adanya sebuah permukiman.

Toponim Patakan muncul di dua prasasti. Prasasti pertama adalah prasasti Těrěp 1032 Masehi yang memberitakan pelarian Airlanga dari Wwatan ke Patakan karena serangan musuh dan prasasti kedua adalah prasasti Pātakan 1021 Masehi yang memberitakan adanya bangunan San் Hyan Patahunan di Patakan. Toponim Patakan masa sekarang kemungkinan berubah menjadi Desa Pataan, Kecamatan 
Sambeng, di Kabupaten Lamongan. Selain itu, juga ditemukan situs kuna yang masih masuk wilayah desa Pataan, Sambeng. Situs tersebut bernama Situs Pataan.

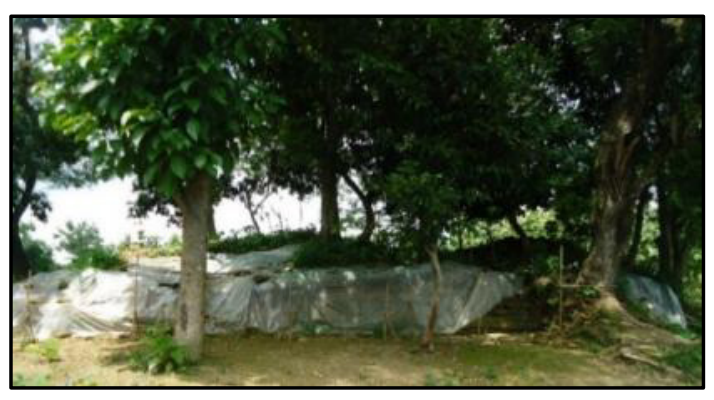

Gambar 1.Situs Pataan dari Arah Timur(Sumber:Dokumen Siswanto, 2013)

Situs Pataan terletak di Dusun Montor, Desa Patakan, Kecamatan Sambeng, Kabupaten Lamongan. Lokasi sekitar situs merupakan areal ladang milik penduduk yang ditanami oleh tanaman jagung. Ekskavasi yang dilakukan oleh Balai Pelestarian Cagar Budaya, Jawa Timur tahun 2013 menunjukkan sebagian besar struktur penyusun bangunan Situs Patakan terdiri atas tatanan batu putih yang berbentuk persegi dengan ukuran yang bervariasi dan saling berkaitan. Struktur Situs Patakan berukuran panjang 16 meter, lebar 10 meter, dan tinggi bangunan diperkirakan sekitar empat meter (Eviana \& Pamungkas, 2016).

Prasasti Tĕrěp memuat tiga toponim yang keberadaannya masih dapat ditemukan di masa sekarang. Toponim pertama adalah Kambangsri yang merujuk pada lokasi pertapaan yang berada di tingkat wilayah thāni. Kambangsri berada di bawah wilayah watak pankaja yang dipimpin oleh seorang Rake yang bernama Dyah Tumambong. Keberadaan toponim kambangsri saat ini telah berubah menjadi Kembangsri, yang masuk wilayah Kabupaten Mojokerto. Peta Rupabumi Indonesia (RBI) yang dikeluarkan oleh Bakosurtanal tahun 1999, lembar Mojosari dan Porong, menunjukkan dua toponim yang mirip dengan toponim Kambangsri, yaitu Bangsri dan Kembangsri. Dusun Bangsri dan Kembangsri masuk wilayah Desa Kembangsri sehingga dapat dikatakan bahwa di Desa Kembangsri kemungkinan nama desa yang disebut dalam prasasti ialah Těrěp.

Desa Turun Hyan yang disebutkan dalam prasasti Turun Hyan sulit ditemukan pada masa sekarang. Nama desa yang memiliki kesamaan dengan nama Turun Hyan hanya dusun yang lokasinya tidak jauh dari lokasi penemuan prasasti. Dusun yang dimaksud adalah dusun Truneng, Desa Mojowono, tetapi perlu dilakukan penelitian lebih lanjut untuk memastikan Dusun Truneng sebagai Desa Turun Hyan. Toponim desa Turun Hyañ berhubungan dengan pemberian hak istimewa kepada penduduk Desa Turun Hyan yang telah membantu raja dalam perang. Perang tersebut disebabkan musuh yang sebelumnya pernah dikalahkan menyerang kembali.

Prasasti Kamalagyan menyebutkan toponim desa yang paling banyak. Secara umum toponim tersebut dapat dibedakan menjadi dua bagian, pertama desa yang berhubungan dengan lokasi dawuhan dan tambak dan kedua merupakan desa yang terkena dampak dari luapan sungai (bengawan) yang bahkan menggenangi beberapa sarana keagamaan yang berada di sekitarnya. Toponim desa yang kemungkinan dapat menjadi bukti lokasi dawuhan dan tambak adalah Kamalagyan dan Waringin Sapta, sedangkan terdampak luapan sungai adalah Lasun, 
Paňjuwan, Sijayanatyěsan, Paňjiganting, Dasapangkah, Pangkaja, dan Thāni Iumput.

Kata kalagyan yang disebutkan dalam Prasasti Kamalagyan merujuk sebagai nama suatu desa. Kalagyan diidentifikasikan sebagai Desa Klagen, yang sekarang berada di Kabupaten Sidoarjo. Desa Klagen merupakan lokasi ditemukannya Prasasti Kamalagyan (Sandi \& Pamungkas, 2015). Menurut Supomo (1977a: 63), kalagyan merupakan bangunan keagamaan untuk agama Hindu aliran Śiwa, seperti pada naskah Arjunawijaya Pupuh 30 Bait 2 dan Nagarakrtagama pada Pupuh 75 Bait 2b (Th. Pigeaud, 1960a:58; 1960b:88).

Asumsi merujuknya kata kalagyan sebagai suatu nama desa perlu dipertimbangkan lagi. Kata kalagyan dalam Kakawin Arjunawijaya (Supomo, 1977a; 1977b) dan Nagarakrtagama (Th. Pigeaud, 1960a; 1960b) merujuk pada salah satu jenis bangunan keagamaan. Jadi, kemungkinan toponim Klagen berhubungan dengan adanya suatu bangunan keagamaan berupa kalagyan

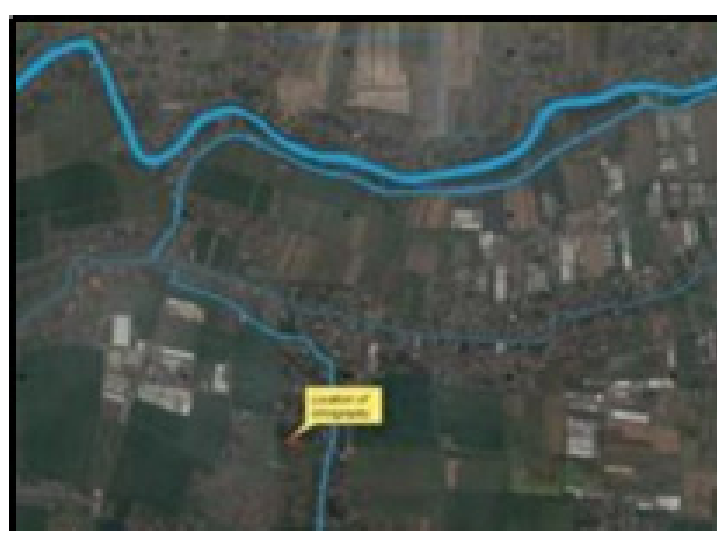

Gambar 2. Lokasi Dusun Waringin Pitu (kiri) dan Lokasi Prasasti Kamalagyan (kanan) di Kabupaten Sidoarjo(Sumber:Google earth dengan perubahan, 2016) yang letaknya tidak jauh dari Desa Kamalagyan dan bangunan keagamaan lain yang disebutkan dalam Prasasti Kamalagyan.

Toponim Desa Lasun, Paliňjwan, Sijayanatyěsan, Paňjiganting, Dasapangkah dan Thāni Jumput tidak dapat ditemukan dalam peta RBI skala 1:25.000 tahun 1999--2000 dan peta topografi yang dibuat oleh Army Map Service, USA skala 1:50.000 yang dikeluarkan sekitar tahun 1940-an. Desa-desa itu kemungkinan sudah berubah nama dan tidak memiliki kemiripan dengan nama desa sebelumnya. Kata Paliňjwan yang merujuk sebagai suatu desa memiliki kemiripan dengan nama Desa Panjunan yang terletak di daerah Sidoarjo. Desa Panjunan berjarak $\pm 3 \mathrm{~km}$ di selatan Kali Mas.

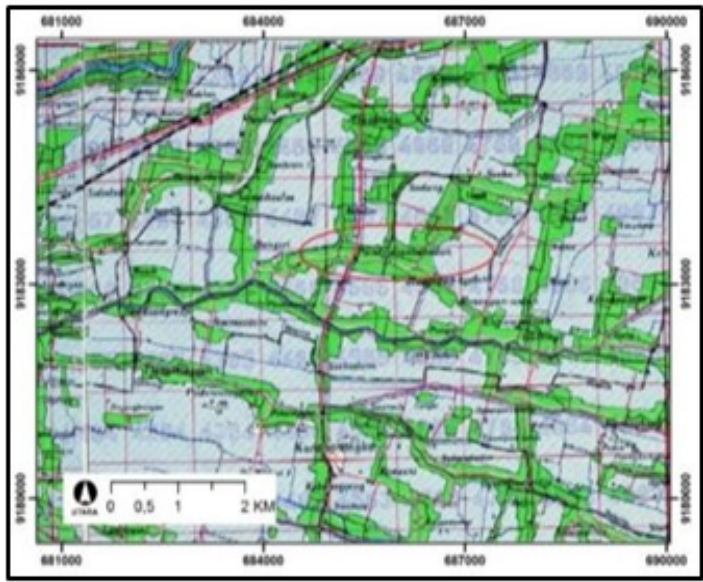

Gambar 3.Lokasi Desa Panjunan, Kabupaten Sidoarjo di peta tahun 1944(Sumber:Army Map Service, 1944 - dengan Perubahan)

Toponim desa lain yang dapat ditemukan sebagai nama desa adalah Pangkaja. Toponim Pangkaja sekarang menjadi nama sebuah dusun di sebelah timur Mojosari, Mojokerto, tepatnya dusun Pengkojo, Desa Tunggalpager (Sandi 
\& Pamungkas, 2015:53). Asumsi itu berdasar pada Nagarakrtagama Pupuh 17 bait 10c, yang kutipannya sebagai berikut (Th. Pigeaud, 1960a:15; 1960b:23):

Len tekan kuṭi ratna pankaja muwah kuṭi haji kuṭi paṅkajādulur

Terjemahan:

Selain itu, sampai di biara Ratna Pangkaja dan juga Kutihaji dan asrama Pangkaja berdampingan.

Pupuh 17 menjelaskan kegiatan Raja Hayam Wuruk yang mengunjungi daerahdaerah kekuasaannya dan dimulai dari sekitar Mojokerto, besar kemungkinannya jika wilayah Pangkaja memang berada di sekitar Mojokerto. Desa Tunggalpager sekarang berjarak $\pm 3.4 \mathrm{~km}$ arah barat Sungai Porong. Informasi dari Prasasti Kamalagyan yang menjelaskan bahwa wilayah Pangkaja terdampak banjir sungai dapat dikatakan benar karena lokasinya yang cukup dekat dengan Sungai Porong.

Prasasti Suměñka menyebutkan adanya desa suměñka. Pada masa sekarang toponim Desa suměñka dapat ditemukan di selatan Kali Mas, yang bernama Desa Sumengko dan masuk Kabupaten Gresik. Toponim Desa Suměñka berhubungan dengan adanya perbaikan sebuah kanal yang dibangun oleh raja terdahulu. Jika benar, kemungkinan adanya kanal tersebut berhubungan dengan pembangunan bendungan yang pernah dibuat oleh Airlañga untuk memperlancar aliran air sehingga tidak terjadi lagi banjir di masa kemudian.

Prasasti Kusambyan menyebutkan adanya toponim Desa Kusambyan. Keberadaan Desa Kusambyan dapat ditemukan kembali dengan nama Desa Kesamben (Nastiti, 2014; Widayanto, 2004), tetapi lokasi Desa Kesamben berada jauh dari lokasi ditemukannya Prasasti Kusambyan sendiri. Jaraknya $\pm 8 \mathrm{~km}$ tenggara dari lokasi penemuan prasasti. Ada dua kemungkinan terkait jarak lokasi toponim Desa Kesamben dan lokasi penemuan. Pertama, kemungkinan pemindahan prasasti pernah dilakukan meskipun prasasti berupa batu. Kedua, tidak ada upaya pemindahan yang pernah dilakukan, tetapi memang wilayah Desa Kusambyan cukup luas sehingga memungkinkan kedua lokasi tersebut saling berjauhan.

Prasasti Kusambyan menyebutkan bahwa di Desa Kusambyan terdapat sebuah keraton yang diserang oleh musuh yang bernama Si Cbek. Akibat serangan itu keraton mengalami kerusakan sehingga penduduk Desa Kusambyan membangun kembali keraton. Sebagai bentuk terima kasih dan balas jasa, raja memberikan anugerah sīma kepada Desa Kusambyan dan penduduk pun membalas anugerah raja dengan memuja Sañ Hyañ Iwak setiap bulan Asuji.

Selain itu, Prasasti Kusambyan menyebut adanya toponim Madaṇ̣̆er. Kitab Pararaton menyebut adanya toponim Badaṇụer. Pada prasasti Sangguran (928 M) dan Pangumulan III (928 M) maḍaṇụ̆r adalah nama tempat kedudukan samgat momahumah (Nastiti, 2014:75). Penyebutan pejabat yang berhubungan dengan penggunaan lahan menjadi bukti bahwa pengaturan perumahan mempunyai peranan yang penting dalam kepentingan suatu kerajaan dan sudah diperhatikan setidaknya sejak abad ke-10 Masehi.

\section{- Pertanian}

Lahan pertanian yang disebutkan dalam prasasti cukup beragam, seperti 
sawah, kebun, ladang, tanah, dan tanah pertanian. Semua jenis lahan pertanian kemudian dikelompokan menjadi dua, yaitu sawah dan kebun. Penjelasan sawah termasuk di dalamnya ladang, tanah, dan tanah pertanian, sedangkan kebun hanya membahas kebun. Hal itu disebabkan penyebutannya yang cukup banyak di prasasti-prasasti.

Rawa dan tepian tidak dimasukkan pada keduanya karena tidak dapat dimasukkan ke dalam pengelompokan sawah atau kebun. Rawa dan tepian disebutkan dalam Prasasti Kamalagyan yang dimiliki oleh raja dan hasilnya harus diserahkan seutuhnya setiap bulan Asuji. Hasil tersebut diserahkan bersama dengan hasil dari tanah pertanian, sawah, ladang, dan kebun.

\section{- Sawah}

Penyebutan sawah ditemuakan pada tiga prasasti, yaitu Prasasti Tĕrĕp, Prasasti Turun Hyan A, dan Prasasti Kamalagyan. Prasasti Tĕrĕp menyebutkan ada tiga sawah yang hasilnya digunakan sebagai penunjang pertapaan di Tĕrĕp yang letaknya di sebelah utara, sawah yang letaknya di sebelah timur luasnya 1 tampah, dan sawah yang letaknya di Wuntalan luasnya juga 1 tampah.

Sawah yang disebutkan dalam Prasasti Turun Hyan் A tidak disebutkan berapa luasnya sehingga tidak dapat dihitung konversi ke satuan meter persegi. Hasil dari sawah tersebut harus dibayarkan sebesar emas 2 suwarna dan dibayarkan setiap bulan Asuji. Menurut (SoesantiYulianto, 1996), Prasasti Kamalagyan menyebutkan adanya dua sawah, tanah pertanian yang luasnya sama dengan kerja sebanyak enam masa dan ladang-ladang.
Satu di antara dua sawah itu luasnya enam tampah. Hasil tanah pertanian dan sawah yang luasnya enam tampah diserahkan kepada raja sebanyak emas 6 suwarna, 7 māsa, 4 kupang.

Naskah Sumanasantaka (Worsley etal. 2013:2014) menceritakan adanya sawah yang diolah oleh seorang pertapa. Sawah dan pertapaan letaknya cukup berdekatan. Sawah tersebutterletak di bawah jurang dengan keadaan sekeliling yang banyak batu-batu besar. Sawah itu kemungkinan ukurannya tidak terlalu luas karena letaknya yang di bawah jurang dan banyak batu-batu besar di sekelilingnya.

\section{- Kebun}

Kebun hanya muncul ditemukan di Prasasti Tĕrĕp, Prasasti Turun Hyan A, dan Prasasti Kamalagyan. Prasasti Turun Hyaṅ menyebutkan adanya sebuah kebun. Kebun tersebut merupakan bagian dari tanah yang tepi utara dan selatannya 118 dpa dan tepi timur dan baratnya 90 dpa. Jika dihitung ukuran keliling kebun tersebut adalah 416 dpa. ${ }^{1}$ Kebun tersebut digunakan sebagai penunjang kebutuhan sebuah pertapan yang bernama Patapan Sri Wijayāśrama.

Prasasti Tĕrĕp menjelaskan lokasi kebun lebih jelas daripada Prasasti Turun Hyan. Kebun yang dijelaskan lokasinya adalah kebun Sirih Pinang yang berada di sebelah timur Babad Hampu, tepatnya berada di selatan jalan. Babad Hampu mungkin sebuah lokasi yang berupa desa, tetapi desa tersebut tidak dapat ditemukan kembali di masa sekarang. Kutipan

\footnotetext{
1 Penghitungannya adalah tepi utara $118 d p a+$ tepi selatan $118 d p a+$ tepi timur $90 d p a+$ tepi barat $90 d p a=416 d p a$.
} 
prasastinya adalah sebagai berikut (Wurjantoro, 2012):

IIIb.

...mwan kubwan papucanan

kidul nin hawan ${ }^{\circ}$ anawetan ${ }^{\circ}$ in babad hāmpu...

Terjemahan:

IIIb.

(1) ...kebun sirih pinang

(2) di selatan jalan ke sebelah timur dari Babad Hāmpu...

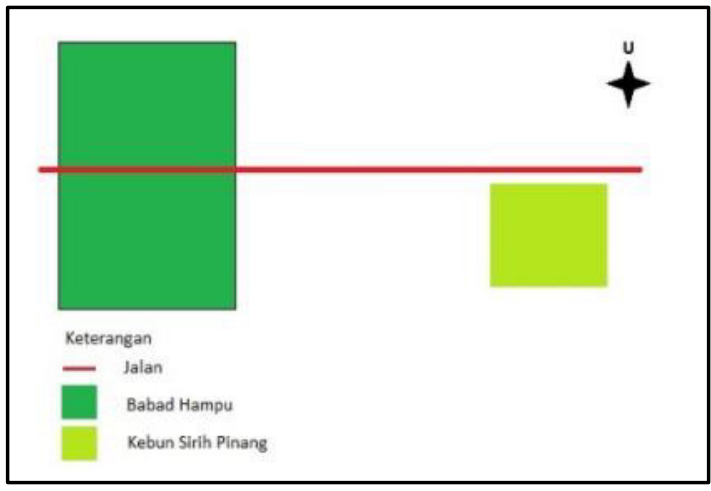

Gambar 4.rekonstruksi lokasi kebun sirih pinang dalam prasasti těrěp(Sumber: Siswanto, 2016)

Kebun yang terletak di Babad Hampu itu berukuran 2 tampah sawah. Selain itu, kebun sirih juga terdapat dalam Prasasti Kamalagyan. Kebun sirih tersebut dimiliki oleh raja, begitu juga dengan sawah, rawa, ladang, dan tepian yang semuanya hasilnya diserahkan kepada raja setiap bulan Asuji.

\section{- Bendungan dan Kanal}

Istilah dawuhan atau bendungan kemungkinan adalah sebuah waduk, bendungan pengalihan, dan cara-cara lain terkait konservasi air dalam skala besar. Terdapat tiga bentuk dawuhan di masa Jawa kuno, yaitu (1) konstruksi bangunan melintang sungai yang bertujuan untuk membendung air sungai, kemudian dapat disalurkan ke saluran pembagi; (2) bangunan pematang di sepanjang sungai yang dibangun dengan tujuan untuk mencegah peluapan air sungai pada masa musim hujan; (3) kolam-kolam penampung air yang dibangun untuk irigasi pertanian yang biasanya dibangun dekat di dekat permukiman Menurut Supratikno Rahardjo (2002:357--36 dan Prasodjo, 2004).

Prasasti Kamalagyan (1037 M) memberikan informasi mengenai pembuatan bendungan dan kanal atau saluran air pemecah aliran sungai besar. Pembuatan bendungan dalam Prasasti Kamalagyan disebabkan sungai meluap dan membanjiri area persawahan, desadesa sekitar, bangunan keagamaan, dan menghambat jalur pedagangan sungai. Peringatan pembuatan bendungan ini dilaksanakan satu hari setelah Airlanga melaksanakan pasowanan ageng dengan dihadap oleh semua raja bawahan yang berhasil ditaklukannya lagi (Poesponegoro, 2010: 208).

Selain itu, Prasasti ini juga memuat puji-pujian terhadap raja sebagai Ratu Cakravarti (penguasa dunia) yang menyirami dunia ini dengan air aměrta yang penuh kasih sayang, menghujankan jasa dan kemasyhuran, dengan memperbaiki semua bangunan dan tempat-tempat suci serta daerah-daerah yang merupakan sīmai, sebagai pendewasaan masa pemerintahannya di mandala Pulau Jawa. Oleh karena itu, raja menyebarluaskan perbuatan darma supaya ditiru oleh rakyatnya dan berlomba-lomba berbuat kebajikan. Akan tetapi, dari kalimat yang menyatakan bahwa raja mengkhawatirkan akan adanya usaha-usaha yang hendak 
menghancurkan semua jasa-jasa yang diperbuat, kelihatan bahwa Airlanga masih belum yakin benar akan ketaatan seluruh wilayah kerajaan pada pemerintahannya (Poesponegoro, 2010: 210).

Kakawin Arjunawijaya memberikan gambaran lebih jelas mengenai bendungan atau dawuhan. Pupuh 38, Bait ke-6c dari suatu waduk terdapat saluran-saluran yang mengalirkan air ke lahan-lahan pertanian dan dari saluran-saluran itu terdapat sebuah saluran utama. Saluran utama berperan sebagai pengendali air sehingga aliran air dapat dikontrol di semua saluran. Selain itu, kegiatan mencari ikan sering dilakukan penduduk di suatu bendungan atau waduk. Kakawin Arjunawijaya Pupuh 39, Bait 4 menyebutkan cara menangkap ikan dengan jaring (warin, pěcak, añco, ser, dan jala) dan dengan jebakan (susug dan karakad). Selain itu, Pupuh 33, Bait 4c menyebutkan cara menangkap ikan dengan cara payan் dan pañcin (Supomo, 1977b:58).

\section{- Bangunan Keagamaan}

Bangunan keagamaan yang dapat diidentifikasi dibagi menjadi bangunan keagamaan Buddha dan Siwa. Pembagian tersebut didasarkan keterangan dalam Kitab Arjunawijaya dan Nagarakrtagama yang memberikan gambaran dalam konteks menjaga dan merawat suatu bangunan keagamaan. Nagarakrtagama memberi gambaran sebagai berikut (Th. Pigeaud, 1960a:58; 1960b:88):

śaiwaḍaksa sira wineh wruha rumakșa parhyanan mwan̉ kalagyan,

bodḍāḍyaksa sireki rakșaka ri sakwehnin kuṭi mwañ wihāra,

mantrī her haji tan̉ kaṛșyan iniwönyān rakṣesa sañ tapaswi
Terjemahan:

Siwadyaksa dia diberi pengetahuan untuk menjaga Parhyangan dan kalagyan,

Buddhadyaksa dia itu menjaga semua kuti (biara Buddha) dan Wihara,

Menteri diperintahkan tinggal oleh Raja, menjaga dan memelihara para pertapa laki-laki.

Sementara itu, dalam Arjunawijaya Pupuh 30,1d-2b, penjelasannya adalah sebagai berikut (Supomo, 1977a:124; 1977b:223):

kaboddhan ika Boddha san் sunana dharma kuṭi-kuṭi lěpas kașadpadan kaśaiwan ika Śaiwa san sunana tasyan analapa kalagyan uttama

kaṛsyan ika walkalîka sira sañ sunana saphala rin̉ wanāśrama

Terjemahan:

di area yang diperuntukkan bagi para penganut Buddha berupa komplek kuil Buddha, kuti (biara Buddha), dan kașadpadan

di area yang diperuntukkan bagi para penganut Śiwa, berupa tasyan dan kepemilikan kalagyan yang paling bagus

di area yang diperuntukkan bagi Rși, yang hidup menyendiri (karena alasan) berupa pertapaan.

Berdasar pada pembagian jenis bangunan keagamaan dalam Nagarakrtagama dan Arjunawijaya, bangunan keagamaan Buddha hanya ditemukan di Prasasti Kamalagyan berupa wihara. Biasanya wihāra dibangun berdekatan dengan sebuah kuți, seperti pada keterangan yang terdapat pada prasasti. Menurut P.J. Zoetmulder dan S.O.Robson (2006), wihāra adalah biara atau candi, aslinya adalah ruangan tempat 
para biarawan bertemu atau berjalanjalan, sedangkan kuți diartikan sebagai bihāra Buddha Sangsang (Darmosoetopo, 2003:204). Soekmono (1974), berdasar Prasasti Kalasan, berpendapat bahwa seluruh bagian bangunan (kuil dan asramanya) disebut wihāra.

Jenis bangunan keagamaan yang disebutkan dalam prasasti sebagian besar adalah bangunan keagamaan yang digunakan bagi para penganutagama Hindu aliran Śiwa, yaitu parhyañan dan patapan. Parhyanan ditemukan dalam Prasasti Pātakan, Turun Hyañ A, Kamalagyan, dan Kusambyan. Prasasti Pātakan menyebut adanya bangunan keagamaan yang bernama San Hyan Patahunan, Prasasti Turun Hyan A menyebut bangunan keagamaan yang bernama San் hyan Sarwwadharmma, Prasasti Kusambyan menyebut adanya pemujaan terhadap San Hyan Iwak, sedangkan Prasasti Kamalagyan hanya menyebut adanya sebuah parhyanan. Menurut Darmosoetopo (2003), parhyanan adalah bangunan untuk memuja hyan atau dewa sehingga bangunan San் Hyan Patahunan, San் hyan் Sarwwadharmma, dan San் Hyan Iwak dapat dikatakan sebagai salah satu bentuk bangunan parhyañan.

Bangunan Patapān i Tĕrĕp, Patapan Śri Wijayāśrama, dan Patapan merupakan bangunan keagamaan yang diperuntukkan bagi para pertapa yang menyendiri karena alasan keagamaan. Bangunan Śala yang disebutkan dalam Prasasri Kamalagyan juga merupakan salah satu jenis bangunan keagamaan. Kamulan, menurutZoetmulder \& Robson (2006), berarti 'bangunan suci'. Prasasti Kamalagyan menyebut adanya sebuah Dharmma rin Isanabraja i surapura. Jones mengatakan bahwa dharmma adalah istilah untuk bangunan keagamaan secara umum (Darmosoetopo, 2003:206). Jadi, Dharmma rin Isanabraja i surapura berarti bangunan keagamaan di Isanabraja yang masuk wilayah Surapura.

Naskah Arjunawijaya menceritakan bahwa pertapaan ditemui ketika rombongan kerajaan berada di sebuah hutan lebat dan menemukan pertapaan yang berada di atas bukit yang tertutupi oleh kabut.

\section{- Hutan}

Prasasti pada masa Airlanga yang digunakan sebagai data penelitian tidak menyebutkan adanya informasi mengenai hutan. Keterangan yang kemungkinan berkaitan dengan hutan hanya mengenai larangan penebangan beberapa jenis kayu dan bambu. Prasasti Kusambyan menyebutkan adanya larangan menebang kayu, bambu, bambu petung, dan jenisjenis pohon tertentu (Nastiti, 2014:73). Kemungkinan besar beberapa jenis pohon dan bambu merupakan jenis kayu yang disebut dengan isitilah kayu larangan.

Informasi adanya hutan dapat ditemukan pada naskah Arjunawijaya. Keterangan itu didapat pada Pupuh 22,6 dan Pupuh 22,7a, yang menyebutkan bahwa setelah rombongan kerajaan melewati banyak desa dan lereng gunung, sampailah di sebuah hutan yang besar (wanâgěn்). Setelah tiba di hutan, rombongan kerajaan melakukan perburuan (burwan). Hasil dari perburuan biasanya berupa daging hewan, seperti babi liar (wěk), burung (seperti merak dan jenis unggas lain), dan kijang (sěñgah) yang merupakan jenis daging hewan yang digemari dalam sebuah jamuan kerajaan, selain daging kambing, kerbau, ikan, dan bebek. Selain itu, di dalam hutan juga 
ditemui sebuah āśrama yang ditempati oleh seorang pertapa (Supomo, 1977a:62).

Gambaran kegiatan perburuan di hutan dapat ditemukan dalam Nagarakrtagama Pupuh 50 sampai dengan 54. Kegiatan perburuan biasanya terdiri atas seorang raja yang membawa seluruh senjata, rombongan pasukan, kereta, dan kudakuda. Setelah itu, pasukan berpencar ke seluruh penjuru hingga seluruh hutan dikelilingi oleh pasukan. Binatangbinatang di dalam hutan berlarian karena ketakutan dan berkumpul di dalam hutan sehingga mudah untuk diburu. Hewan yang berhasil didapatkan berupa babi hutan, kijang hitam, dan cihna (sejenis kijang kecil) sehingga menyebabkan hutan yang sebelumnya lebat menjadi terbuka (Th. Pigeaud, 1960a:37--40; 1960b:56-62).

\section{SIMPULAN}

Bentuk penggunaan lahan yang berhasil diidentifikasi dalam prasasti berupa permukiman, pertanian, bangunan keagamaan, dan hutan. Penggunaan lahan untuk pertanian terdapat tiga bentuk, yaitu sawah, kebun, dan bendungan (serta kanal). Keseluruhan bentuk penggunaan lahan tampaknya memiliki latar belakang penggunaannya. Hasil analisis menunjukkan bahwa latar belakang suatu lahan digunakan tampaknya tidak hanya bertujuan ekonomi atau religi, tetapi terdapat alasan politik yang kuat.

Alasan politik dapat ditemukan dalam beberapa bentuk seperti (a) Airlangga menyamakan dengan Ratu Cakravarti 'sang penguasa dunia'; (b) pasowanan besar dapat disamakan sebagai upaya pengumuman kemenangan atas peperangan yang pernah dilakukan dan berhasil menaklukan kembali raja-raja yang sebelumnya pernah ditaklukan; (c) penyebutan raja sebagai chatra nin bhuwana atau 'payung dunia' dapat diartikan sebagai pemberi ketentraman, keamanan, dan kesejahteraan bagi masyarakat ketika raja berhasil mengalahkan musuh dalam peperangan; (d) balas jasa ketika terjadi penyerangan oleh musuh. Balas jasa tersebut berhubungan erat dengan penyebutan raja sebagai "payung dunia" yang memberikan ketentraman, keamanan, dan kesejahteraan bagi masyarakat; (e) penggunaan tanda garuḍamukhalāñchanā pada prasasti yang dikeluarkan oleh raja Samarotsāha membutikan alasan politik yang kuat. Raja Samarotsāha memerintah jauh setelah Airlanga wafat. Tanda garuḍamukhalāñchanā lazim ditemui di prasasti yang dikeluarkan oleh Airlanga. Hal ini membuktikan bahwa ada hubungan antara Samarotsāha sebagai raja yang mengeluarkan status sìma dengan Airlañga. Kemungkinan tanda garuḍamukhalāñchanā dapat menunjukkan legitimasi politik yang dilakukan oleh Samarotsāha atas kepemimpinannya sebagai seorang raja.

Penelitian ini juga menegaskan bahwa dari beberapa prasasti yang dikeluarkan sekitar masa Airlanga memerintah hingga digantikan oleh raja lain, alasan yang mendasari dikeluarkannya keputusan lewat prasasti lebih didominasi oleh alasan politik, terutama prasasti-prasasti yang berkaitan dengan balas jasa. Beberapa prasasti juga dikeluarkan karena alasan ekonomi dan religi, tetapi dominasi alasan politik yang cukup kuat. 


\section{DAFTAR PUSTAKA}

Brandes, J. L. . (1913). Oudh-Javaansche Oorkonden. Nagelaten Transcripties van Wijlen Dr. J.L.A Brandes uitgegeven door Dr. N.J Krom. Batavia - S' Hague: Albrect \& Co, M. Nijhoff.

Christie, J. W. (1999). Register of the Inscription of Java 732 - 1060 A.D. (The Inscription of Mataram).

Damais, L. (1952). I . Etudes d â€ $€^{\mathrm{TM}}$ épigraphie indonésienne : III. Liste Des Principales Inscriptions Datées De L'Indonésie. Bulletin de I'Ecole Française d'ExtrêmeOrient., (Tome $47 \mathrm{~N}^{\circ} 1$ ), 1-106.

Damais, L. (1955). II . Etudes d â€ $€^{\mathrm{TM}}$ épigraphie indonésienne : IV . Discussion de la date des inscriptions. In Bulletin de I'Ecole française d'Extrême-Orient. (pp. 7-290).

Darmosoetopo, R. (2003). Sima dan Bangunan Keagamaan di Jawa Abad IX-X TU. Yogyakarta: Prana Pena.

De Casparis, J. G. (1958). Airlangga. Pidato Pengukuhan Jabatan Guru Besar Sejarah Indonesia Lama dan Bahasa Sanskerta, Universitas Airlangga. Surabaya: Penerbit Universitas.

Dwiyanto, D. (1993, August). Metode Penelitian Epigrafi dalam Arkeologi. ARTEFAK No.13, 7-9.

Eviana, \& Pamungkas, Y. H. (2016). Arti Historis Prasasti Patakan Dalam Jejak Airlangga di Lamongan. AVATARA E-Journal Pendidikan Sejarah, 4(2), 284-296.

Kusumohartono, B. (1994). "Data Baru” Dari Distribusi Artefak Prasasti. Berkala Arkeologi Edisi Khusus, XIV, 17-21.

Nastiti, T. S. (2014). Prasasti Kusambyan: Identifikasi Lokasi Maḍaṇụ̆er dan Kusambyan. Amerta, Jurnal Penelitian Dan Pengembangan Arkeologi, 69-79.

Poesponegoro, M. D. (2010). Sejarah Nasional Indonesia. (N. Notosusanto, Ed.) (Cetakan ke). Jakarta: Balai Pustaka.

Prasodjo, T. (2004). Kemajuan Teknologi Masa Airlangga: Contoh Kasus Pembangunan Tambak atau Dawuhan dalam Prasasti Kamalagyan. In Airlangga Sebagai Tokoh. Jombang: Pusat Penelitian Arkeologi Nasional.

Sandi, A. D., \& Pamungkas, Y. H. (2015). Banjir Sungai Brantas Masa Raja Airlangga Abad XI Berdasarkan Prasasti Kamalagyan 1037 M. AVATARA E-Journal Pendidikan Sejarah, 3(1), 50-57.

Soekmono. (1974). Candi Fungsi dan Pengertiannya. Universitas Indonesia.

Soesanti-Yulianto, N. (1996). Prasasti-prasasti Sekitar Masa Pemerintahan Raja Airlangga: Suatu Kajian Analitis. Depok.

Supomo, S. (1977a). Arjunawijaya, a Kakawin of Mpu Tantular. Volume I. Leiden: 


\section{KITLV.}

Supomo, S. (1977b). Arjunawijaya, a Kakawin of Mpu Tantular. Volume II. Leiden: KITLV.

Th. Pigeaud, T. G. (1960a). Java In The 14th Century Volume I. The Hague: Martinus Nijhoff.

Th. Pigeaud, T. G. (1960b). Java in the 14Th Century Volume III. The Hague: Martinus Nijhoff.

Widayanto, W. (2004). Prasasti Kusambyan. Universitas Indonesia.

Worsley, P., Supomo, S., Fletcher, M., \& Hunter, T. . (2014). Kakawin Sumanasāntaka, Mati karena Bunga Sumanasa. Kajian sebuah puisi epik Jawa Kuno (Naskah dan). Jakarta: EFEO - KITLV - Yayasan Obor Indonesia.

Worsley, P., Supomo, S., Hunter, T., \& Fletcher, M. (2013). Mpu Monaguna's Sumanasāntaka. An Old Javanese Epic Poem, its Indian Source and Balinese Illustrations. (P. Worsley, S. Supomo, T. Hunter, \& M. Fletcher, Eds.) (Bibliothec). Leiden: Brill.

Wurjantoro, E. (2012). Prasasti Berbahasa Jawa Kuno Abad Viii-X Masehi Koleksi Museum Nasional Jakarta (alih aksara dan terjemahan). Depok.

Zoetmulder, P. ., \& Robson, S. . (2006). Kamus Jawa Kuna Indonesia. Jakarta: Gramedia Pustaka Utama. 


\section{Lampiran}

Tabel 2. Penggunaan Lahan pada Prasasti

\begin{tabular}{|c|c|c|c|c|c|c|}
\hline \multirow{2}{*}{$\begin{array}{c}\text { Nama } \\
\text { Prasasti }\end{array}$} & \multirow{2}{*}{$\begin{array}{l}\text { Tahun } \\
\text { (Masehi }\end{array}$} & \multicolumn{2}{|c|}{ Toponim } & \multirow{2}{*}{ Pertanian } & \multirow{2}{*}{$\begin{array}{c}\text { Bangunan } \\
\text { Keagamaan }\end{array}$} & \multirow{2}{*}{ Hutan } \\
\hline & & Dulu & Sekarang & & & \\
\hline Pātakan & 1021 & Pātakan & $\begin{array}{l}\text { Pataan, Lamon- } \\
\text { gan }\end{array}$ & - & $\begin{array}{l}\text { Sañ hyan } \\
\text { patahunan ri } \\
\text { pātakan }\end{array}$ & - \\
\hline Těrěp I, II & 1032 & $\begin{array}{l}\text { Kambañ Śr̄̄ } \\
\text { Wuntalan } \\
\text { Babad Hāmpu } \\
\text { Pātakan } \\
\text { Wwatan Mās }\end{array}$ & $\begin{array}{l}\text { Kembangsri, } \\
\text { Mojokerto } \\
- \\
- \\
\text { Pataan, Lamon- } \\
\text { gan } \\
\text { Wotanmas Je- } \\
\text { dong, Mojokerto }\end{array}$ & $\begin{array}{l}\text { Sungai } \\
\text { Sawah } 1 \text { tam- } \\
\text { paḥ di sebelah } \\
\text { uatara } \\
\text { Sawah di sebe- } \\
\text { lah timur } \\
\text { Sawah 1 } \\
\text { tampah̆ di } \\
\text { Wuntalan } \\
\text { Kebun sirih } \\
\text { pinang } 2 \\
\text { tampah }\end{array}$ & $\begin{array}{l}\text { Patapān i } \\
\text { těrěp lmah } \\
\text { kambań śrī }\end{array}$ & - \\
\hline $\begin{array}{l}\text { Turun } \\
\text { Hyan் A }\end{array}$ & 1036 & Turun Hyan் & $\begin{array}{l}\text { Truneng, Mojok- } \\
\text { erto }\end{array}$ & $\begin{array}{l}\text { Kebun yang } \\
\text { kelilingnya } \\
416 d p a \\
\text { sawah }\end{array}$ & $\begin{array}{l}\text { Sañ hyan் } \\
\text { Sarwwad- } \\
\text { harmma } \\
\text { Patapan Śri } \\
\text { Wijayāśrama }\end{array}$ & - \\
\hline $\begin{array}{l}\text { Kamalag- } \\
\text { yan }\end{array}$ & 1037 & $\begin{array}{l}\text { Kamalagyan } \\
\text { Waringin sapta } \\
\text { Lasun } \\
\text { Paliňjuwan } \\
\text { Sijayanatyěsan } \\
\text { Paňjiganting } \\
\text { Dasapangkah } \\
\text { Pangkaja } \\
\\
\text { thāni jumput }\end{array}$ & $\begin{array}{l}? \\
\text { Dusun Waringin- } \\
\text { pitu, Desa Baka- } \\
\text { lan Waringinpitu, } \\
\text { Sidoarjo } \\
? \\
? \\
? \\
? \\
? \\
\text { Pengkojo, Mojo- } \\
\text { sari, Mojokerto } \\
?\end{array}$ & $\begin{array}{l}\text { Tanah per- } \\
\text { tanian yang } \\
\text { luasnya sama } \\
\text { dengan kerja } \\
\text { sebanyak } 1 \\
\text { masa } \\
\text { sawah } 6 \text { tam- } \\
\text { pah } \\
\text { Ladang-ladang } \\
\text { Kebun sirih } \\
\text { Sawah } \\
\text { Rawa } \\
\text { Tepian }\end{array}$ & $\begin{array}{l}\text { Dharmma rin } \\
\text { isanabhawa- } \\
\text { na i Surapura } \\
\text { Wihāra } \\
\text { Sāla } \\
\text { Kamūlan } \\
\text { Parhyañan } \\
\text { Patapan }\end{array}$ & - \\
\hline Suměñka & 1059 & Suměñka & $\begin{array}{l}\text { Desa Sumengko, } \\
\text { Gresik }\end{array}$ & - & - & - \\
\hline $\begin{array}{l}\text { Kusamb- } \\
\text { yan }\end{array}$ & $?$ & $\begin{array}{l}\text { Maḍaṇ̣̆er } \\
\text { Kusambyan }\end{array}$ & $\begin{array}{l}\text { Dusun Bedander, } \\
\text { Jombang } \\
\text { Desa Kesamben, } \\
\text { Jombang }\end{array}$ & - & $\begin{array}{l}\text { San் hyan } \\
\text { iwak }\end{array}$ & $\begin{array}{l}\text { Informa- } \\
\text { si kayu } \\
\text { larangan }\end{array}$ \\
\hline
\end{tabular}

